\title{
Research on the Development Status and Strategies of the Cruise Industry of Shanghai
}

\author{
Yan Yin ${ }^{1, a}$, Yiyang $\mathrm{Liu}^{2, \mathrm{~b}}{ }^{*}$ \\ ${ }^{1}$ College of Economics and Management, Shanghai Ocean University, Shanghai, 201306, China \\ ${ }^{2}$ Marine Economy Research Center, Shanghai Ocean University, Shanghai, 201306, China \\ * Corresponding Author: Liu Yiyang
}

Keywords: Cruise industry of Shanghai, Development status, Policy suggestions

\begin{abstract}
With a view to global cruise industry development, this paper combines the development advantages of the cruise industry of Shanghai, and proposes the following centering the main issues faced by the development of the cruise economy of Shanghai: The cruise industry of Shanghai shall make use of its own advantages and see the middle and lower stream of the industry chain as the strategic entry points, realizing a two-way development strategy that combines the construction of a home port and the founding of local cruise companies; keep releasing the driving effects of cruise industry upon regional economy, and deploy supporting policies as efforts that facilitate Shanghai to become an international center of cruises in Asia Pacific.
\end{abstract}

\section{Global cruise industry development}

Global Market Maintains a Rapid Growth. Chinese market becomes a highlight. Cruise industry first began in North America during 1970s, which is now one of the most exciting tourist projects in global leisure and relaxation market. The data of Cruise Lines International Association (CLIA) shows that the number of tourists attended international cruise lines increased from 6.25 million passengers to 21 million passengers from 1996 to 2012, which is almost an eightfold growth. Land tourist demand during the same period, however, only increased by $50 \%$. It is expected that the number of global cruise passengers will reach 25 million and 30 million by 2015 and 2020 respectively.

China owns a coastline that is $18,000 \mathrm{~km}$ long where important ports of departure and destinations for summer cruise lines as well as important ports of call for winter cruise lines in Asia are located. The cruise market scale in China in 2014 witnessed a growth as high as 103\%, the number of entry and exit through cruise exceeded 1.6 million, and the numbers of reception of cruises at ports and those who enter and exit China via cruises both doubled than those in 2013.

The Development Focus of the Industry Shifted Eastward to Asia Pacific, and the Investment Willingness in China Has Been Running High. Currently, the situation of global cruise market can be described as "matured in North America, continuously growing in Europe and emerging in Asia”. International cruise companies are strengthening their investment in Asia Pacific market. Statistics of CLIA show that the fastest growing markets in the world are Australia and Asia (largely China). The shares of cruise lines of Asia and Australia from 2008 to 2013 increased dramatically, and the shares of Asian cruise lines increased from 1.2\% in 2008 to 3.6\% in 2013, the needs for cruise tour increased nearly 300\% in five years. Meanwhile, a number of global top cruise companies are entering Chinese market such as Royal Caribbean, Costa Cruises, Star Cruises, and Princess Cruises.

As the cruise tour market in China becomes increasingly popular, and the issuing of a series of national and local cruise industry policies, more and more Chinese enterprises are beginning to get involved in the business. At the end of 2011, Hainan Airlines purchased "Henna" from Carnival Cruises, which made its maiden trip in Phoenix Island of Sanya in 2013. February 2014, Bohai Cruises, an affiliated company of Bohai Ferry purchased "Costa" at a price of 43.68 million USD, and converted it into "Chinese Taishan", which has been well received in the market. September 2014, 
SkySea Cruise Line, an affiliated company of Ctrip purchased "Celebrity Century” from Royal Caribbean, which is now under interior transformation.

Obvious Upsizing of Cruises, and Significant Industry Spillovers. Currently, the models of cruises in Asian market are mainly 50,000 to 80,000 tons, and the flagship models in Chinese market also gradually upsize from 80,000 tons to 100,000 tons. The number of large-scale and young vessel-age cruises which are based in Chinese ports keeps increasing, such as Quantum, Mariner of the Seas, Voyager, Sapphire Princess, and Oasis of the Seas.

The cruise industry is also known as "a golden industry that floats on sea”. Being promoted by the upsizing of international cruises, the industry is bringing more significant driver effects upon neighboring areas near cruise ports and relevant industries. According to CLIA (the contributions made by the cruise industry in North America in 2013 to the US economy), the direct contribution ratio of the cruise industry of North America in 2013 is as high as 1:5, and the direct economic contribution per capita is as high as 1889 USD, and the total economic contribution per capita is 3899 USD.

\section{Advantages of the Development of the Cruise Industry of Shanghai}

Regional Advantages. Shanghai is located in the center of China's eastern coastline, and it is the estuary of Yangtze River, the center of Yangtze River Delta. It covers the entire Yangtze River Basin and connects the world. Boarding a luxurious cruise in Shanghai and you can reach Japan, South Korea, Singapore, Hong Kong and Taiwan in 48 hours.

Market Advantages. China is the highlight of the growth of cruise market in Asia Pacific, and Shanghai is the fastest-growing market out of China's cruise market. The permanent resident population of Shanghai is nearly 24 million. The traffic connections between Shanghai and economically developed Yangtze River Delta have been becoming increasingly intimate, offering sufficient potential passenger source for the development of the cruise industry. The exit \& entry statistics of Shanghai show that the times of cruise exit and entry of Shanghai in 2013 is nearly 600, a year-on-year growth of 33\%, among which nearly 400 times were luxury liners, a year-on-year growth of $61 \%$. The times of passenger exit and entry of Shanghai is nearly 800,000 , a year-on-year growth of nearly $20 \%$.

Home port Advantages. The shoreline of Shanghai North Bund International Passenger Terminal is $880 \mathrm{~m}$, supporting the berth of three 70,000-ton cruises, and the terminal is capable of allowing 1 million people for exit and entry each year; the total area of Wusongkou International Cruise Market is over 1.6 million square meters, allowing three large-scale cruises that are 100,000 tons to 150,000 tons to park simultaneously. In 2015, a total of 8 cruises of Costa, Royal Caribbean, Princess Cruises, and SkySea Cruises selected Shanghai as their home port, marking that Shanghai has officially become a home port of international cruises.

Policy Advantages. In recent years, a series of national and Shanghai local policies that support the cruise industry were released. In September 2012, the first “Development Experiment Zone for China's Cruise Tour" which was approved by National Tourism Administration was founded in Baoshan District. With the opportunities brought by Shanghai Free Trade Zone, Shanghai offers 72-hour transit visa-free policy for citizens from 45 countries. The Waterways Traffic Bureau of Ministry of Communications also selected Shanghai as the trial place for cruise transport.

\section{The Research Thought of the Development of the Cruise Industry of Shanghai}

Strategic Entry Point. Viewing global cruise industry chain from the perspective of middle and downstream, as well as the "two-way forward" strategy, European countries such as Germany, Italy, Finland and France have been occupying the upper stream of the industry chain in terms of liner design, manufacture and maintenance for a long time. Newly founded cruise companies such as Hainan Airlines Cruises, Bohai Cruises and SkySea Cruises are still at the exploring stage where they are far behind international level whether in service quality or profitability. As for route design, most 
of which are middle and short routes to Japan, South Korea and Southeast Asia, and the training of cruise-related personnel and overall consumption concepts are still waiting to be enhanced.

With its own advantages, Shanghai shall firmly grasp the opportunity to develop the cruise industry and follow the principle of "do the right things" to reasonably distribute the division system of the value chain of the cruise industry, and start from the middle and downstream, adopt two-way forward strategies which are the building of home port and founding of local cruise companies.

Home Port Building. International experiences shall be borrowed, and the matching between industry and functions shall be enhanced. Major cruise home ports in the world are mostly located in countries and regions such as the US, Canada, Spain, Australia, Singapore and Hong Kong. As a symbolic international cruise home port, the key functions of Miami of the US include sufficient berths, berthing times and number of passengers.

Wusongkou International Cruise Port has preliminarily become a home port, but it still has to make improvement in terms of hardware facilities when compared with international cruise home ports, especially industry and function matching. Happily, the subsequent auxiliary projects of the first phase of Wusongkou International Cruise Port has been officially launched in 2015. Two additional home port berths will be added in Wusongkou International Cruise Port after the transformation, forming the " 3 home port berths +1 affiliated berth" berthing system. New large-scale parking section and loading/unloading section will be added, and the approach bridge will be expanded. It is estimated that the passenger throughput of Wusongkou International Cruise Port will be 3 million / year by 2020, and capable of receiving 450 berths / year, so that all of its hardware facilities may meet the requirements of top-ranking international cruise home port.

In order to further improve the level of Wusongkou International Cruise Port, the study of matching industry policies shall be accelerated on the one hand to actively attract more international and domestic cruise-related enterprises to settle in; on the other hand, the support of Shanghai municipal and Baoshan district governments shall be obtained to accelerate the development and construction of surrounding areas of the port, and tourist business facilities such as restaurants, hotels, iconic landscapes, museums, waterfront plazas, movies and theaters, entertainment centers and shopping malls shall be reasonably planned and constructed, as an effort of making Wusongkou International Cruise Port a top-ranking international cruise home port in Asia Pacific.

Founding of Local Cruise Companies. Integrating resources and founding joint-venture companies. In order to emphasize the contributions made by the cruise industry to the development of industry and economy of Shanghai, another important breach of strategic development thoughts is about founding local cruise companies in consideration of the current foundation of the cruise industry of Shanghai. From the perspective of development mode, there are at least two kinds of operational modes, including self-run, joint-operation, and three plans to found local cruise companies.

Self-run plan 1: Start from small, as in a single ship and then try to expand the scale. Pattern: Purchase or rend a second-handed international liner of smaller tonnage, which then goes through modification for localization, and then try to launch some domestic routes and use Shanghai as the home port for staggering competition with international cruise companies. Advantages: (1) Small investment, liners of smaller tonnage can be selected which means less fierce market competition; (2) Independent development, and it is not necessary to introduce brands, sales network and management team of international cruise companies; (3) With single-ship operation, the industry chain can be extended to accumulate experiences for subsequent development. Disadvantages: (1) Difficult to form complete sales network and management team; (2) Unable to directly compete with international cruise companies; (3) A big number of competitors in China.

Self-run plan 2: Build a cruise fleet through M\&A. Method: M\&A via assets acquisition or equity merger to build an international cruise fleet of certain scale with complete brands, management team and sales network. Advantages: (1) Higher starting point, allowing the company to enter the cruise industry quicker and create size effects, breaking the situation where the cruise industry is controlled by other countries; (2) Obtaining the right of speech in China and Asian market; (3) Stronger ability 
to resist periodic risks in the market. Disadvantages: (1) Huge investment; (2) Difficult operations and management, as well as higher market and operational risks.

Joint-operation plan: Founding of a state-owned holding and joint-venture cruise company. Method: The port company, shipping service company and travel agency work together, and found a joint-venture cruise company with a foreign cruise company which obtains multiple cruises. Investment includes cash, stock rights or other intangible assets. Advantages: (1) All resources can be integrated, gaining comprehensive competitive advantages; (2) Improving the operation and management level of local enterprises; (3) Forming a barrier against other international cruise companies from entering Chinese market by increasing the M\&A cost. Disadvantages: (1) How to reasonably balance the requests of different parties for resources and benefits; (2) Foreign investment may not exceed $49 \%$ and may not operate the cruise market between Taiwan Straits (unless approved) according to the Ordinance of International Carriage of Goods by Sea, forming a policy barrier.

Therefore, this paper suggests that the plan 3 shall be the primary plan for the founding of local cruise companies, which is a process that shall be market-oriented, led by government policies. Well-known travel and cruising companies work together with well-known cruise companies in the world to found state-owned holding joint ventures for joint-operation, promoting the cruise industry of Shanghai to accelerate its development from a higher level.

\section{Relevant Policy Suggestions}

Access Policies for International Cruise Companies. Foreign cruise companies shall be attracted to present in Shanghai. Management methods regarding foreign cruise companies registering and founding operational organizations and applying for international cruise routes shall be carried together with relevant government departments. The procedures of foreign cruise companies setting up holding or exclusively owned companies in Shanghai shall be simplified. Those companies of which the global or regional HQ relocate to Shanghai shall enjoy relevant preferential policies of Shanghai Municipal People’s Government. Application procedures for those companies setting up offices in Shanghai shall be simplified.

Preferential Policies for Home Port Cruise Companies. Unified charging shall be conducted and charging standard shall be lowered. Existing charging items at ports are too many and too high including fees for pilotage, tying-up, harbor dues, vessel agency and passenger transport agency etc. It is suggested that relevant government departments shall rearrange such fees, and carry out preferential policies for cruise companies. Financial and taxation policy pilot shall be set up for cruise companies, and support from departments of central government shall be obtained. For cruise companies which are recognized that their HQs are based in Shanghai, a 15\% income tax reduction shall be provided. For cruise companies registered in Shanghai, and products that starts or ends in Shanghai, certain amount of capital subsidies shall be provided.

Other Supporting Policies. A financial service system that facilitates the development of the cruise industry shall be accelerated. The opportunities brought by the Free Trade Zone shall be firmly grasped and single-cruise financing rental company shall be set up, which is exempted from business tax. Cruise companies registered in Shanghai are allowed to set up offshore accounts, offering support for the capital settlement of their overseas businesses.

\section{Acknowledgements}

The research was supported by Open Project of Marine Science Research Center of Shanghai Ocean University (Grant No. A1-0203-16-300121), Doctoral Initial Funding of Shanghai Ocean University (Grant No. A2-0203-00-100354) and the Special Fund of Shanghai Ocean University (Grant No. A2-0203-00-100468). 


\section{References}

[1] Pan Qinfen. Mode of the Development of International Economic of Cruise Line and Its Implication for China [J]. Science Technology and Industry, 2007, 7(10): 13-17+24.

[2] Zhu Binjiao, Yan Chenguang. Research on Development and Problems of Shanghai Cruise Supply Industry [J]. Communication \& Shipping, 2015(2): 59-63+82.

[3] Ye Xinliang, Sun Ruihong. Research on Cruise Industry of Tourism in Shanghai based on Customer Demand [J]. East China Economic Management, 2007, 21(3): 110-115.

[4] Wang Chuanxiu. Bottleneck and Countermeasures of Implementation of the Cruise Ship Shore Power in Shanghai [J]. Scientific Development, 2016(10):85-88. 